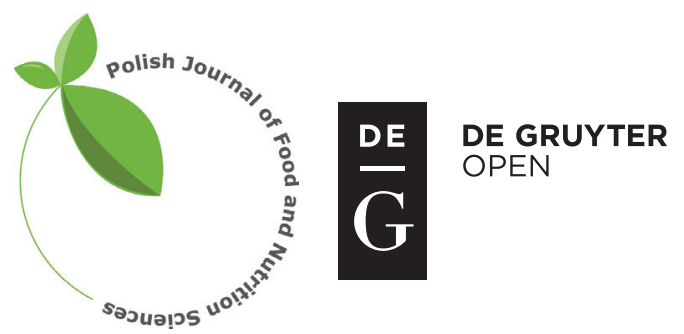

Pol. J. Food Nutr. Sci., 2017, Vol. 67, No. 3, pp. 241-244

DOI: $10.1515 /$ pjfns-2016-0030 http://journal.pan.olsztyn.pl

Short report

Section: Food Technology

\title{
Content of TDF, SDF and IDF in Cereals Grown by Organic and Conventional Farming - a Short Report
}

\author{
Mirjana Menkovska ${ }^{1, *}$, Vesna Levkov ${ }^{1}$, Dragan Damjanovski², Natasha Gjorgovska ${ }^{1}$, \\ Desimir Knezevic ${ }^{3}$, Nedeljka Nikolova ${ }^{1}$, Danica Andreevsk ${ }^{4}$
}

\author{
${ }^{I}$ Ss. Cyril and Methodius University, Institute of Animal Science, bul. Ilinden 92a, 1000 Skopje, Macedonia \\ ${ }^{2}$ University St. Klement of Ohrid, Faculty of Technology and Technical Sciences, ul. Petre Prlickov 42, 1400 Veles, Macedonia \\ ${ }^{3}$ University of Prishtina, Faculty of Agriculture, Kosovska Mitrovica, Lesak, \\ Kopaonicka bb. 38219 Lesak, Kosovo and Metohia, Serbia \\ ${ }^{4}$ Ss. Cyril and Methodius University, Institute of Agriculture, ul. 16-ta Makedonska Brigada 3a, 1000 Skopje, Macedonia
}

Key words: dietary fibre fractions, wheat, barley, rye, oat, millet

The objectives of this article were to determine the content of total dietary fibre (TDF) as well as of its fractions - soluble dietary fibre (SDF) and insoluble dietary fibre (IDF) of different cereals grown by conventional and organic farming in Macedonia, as well as to find out the influence of the cereal type and farming method on their values. Standardized enzymatic-gravimetric method (Megazyme Total Dietary Fiber Kit) was used for determination of soluble, insoluble, and total dietary fiber in 27 different cereal samples of wheat, rye, barley, oat, and millet, which were grown at three locations. The content of TDF, IDF and SDF was influenced by both cereal type and farming type. The organically grown cereals, primarily oat and barley, have shown higher values of TDF and of its fractions than the conventionally grown cereals. Their values (\% db) for oat and barley for TDF were $42.00 \pm 1.39$ and $21.91 \pm 2.01$, for IDF $39.22 \pm 0.58$ and $15.06 \pm 1.84$ and for SDF $2.78 \pm 1.25$ and $6.85 \pm 3.85$, respectively. Barley grown by either organic or in conversion farming method proved to have the highest value of SDF content among the other cereals investigated, whereas oat produced by organic farming method exhibited the highest values of TDF and ISF content. The organic farming method proved to have a good perspective in cereal processing and technology, food market and nutrition.

\section{INTRODUCTION}

A high dietary fiber (DF) intake is generally recommended for proper nutrition on the base of its resistance to digestion and the health benefits of its consumption, so the quantification of DF in foods has been of significant interest for over 30 years. Observational studies as well as epidemiological data have showed associations between high-fibre diets and reduction in many diseases [Jones, 2013]. Investigations were performed on physiological effects and health consequences of DF intake [Cho \& Blaser, 2012], on associations with lower blood pressure [Vernay et al., 2012], on weight management, cholesterol reduction and glycemic control [Babio et al., 2010], and on appetite control [Kristensen \& Jensen, 2011].

According to the definition of DF [FAO/WHO Food Standards Programme, Secretariat of the CODEX Alimentarius Commission, 2010]: "dietary fiber consists of carbohydrate polymers with ten or more monomeric units, which are not hydrolyzed by the endogenous enzymes in the small intestine of humans and belong to the following categories: a) edible carbohydrate polymers naturally occurring in the food as con-

\footnotetext{
* Corresponding Author: E-mail: menkovska06@yahoo.com Methods 985.29 and 991.43 [Mc Cleary et al., 2013].

sumed; b) carbohydrate polymers which have been obtained from food raw material by physical, enzymatic or chemical means and which have been shown to have a physiological effect of benefit to health, and c) synthetic carbohydrate polymers which have been shown to have a physiological effect of benefit to health. When derived from a plant origin, dietary fiber may include fractions of lignin and/or other compounds when associated with polysaccharides in the plant cell walls and if these compounds are quantified by the AOAC gravimetric analytical method for dietary fiber analysis: fractions of lignin and the other compounds (proteic fractions, phenolic compounds, waxes, saponins, phytates, cutin, phytosterols, etc.) intimately "associated" with plant polysaccharides in the AOAC 991.43 method. Decision on whether to include carbohydrates of 3 to 9 monomeric units should be left up to national authorities".

A proper and adequate analytical methodology and food labeling regulations are based on an accurate definition [Devries, 2004]. A number of AOAC Official Methods of Analysis have been adopted for the analysis of dietary fibre and some of its fractions and components are consistent with the state of dietary fiber science [Jones, 2013; McCleary et al., 2013]. Over the past two decades, the most widely used methods for the measurement of dietary fibre have been AOAC 
Cereal grains are naturally rich in DF, and provide in many countries the most abundant source of DF in the diet. European Food Safety Authority recommends the minimum amount of DF for adults of $25 \mathrm{~g}$ /day [EFSA, 2010]. DF is classified into insoluble and soluble components based on water solubility and fermentability [Devinder et al., 2012]. Soluble DF components are quantitatively and qualitatively important in many foods. The cell walls of cereal grains are a major source of soluble and insoluble DF in the daily diet [Saulnier et al., 2007; Hemery et al., 2007].

Organic farming, as a way of food producing that respects natural life cycles and minimizes the human impact on the environment and operates in accordance with objectives and principles by maintaining biodiversity and fostering healthy soil and growing conditions nowadays is also attracting more interest for food production in the EU, world and our country. It is regulated with European and national regulations [Council Regulation (EC) No. 834, 2007; USDA Agricultural Marketing Service. Fact Sheet: National Organic Production and Handling Standards, 2008; Official paper of RM, 2009]. In comparison with the conventional farming, the regulations for organic farming prohibit most synthetic (and petroleum derived) pesticides and fertilizers, antibiotics, genetic engineering, irradiation and sewage sludge. There are requirements for all organically-produced animals to have $100 \%$ organic feed without any animal by-products or growth hormones, and processed products labeled organic should contain at least $95 \%$ organic ingredients [Morgan \& Murdoch, 2000].

This study is a continuous research done on the quality of cereals grown by organic and conventional farming [Menkovska et al., 2014]. The objectives of this paper were: to determine the content of dietary fibre and of its components: soluble and insoluble dietary fibre of different cereals grown by conventional and organic farming in the country, as well as to find out the influence of cereal type and farming method on their values.

\section{MATERIALS AND METHODS}

\section{Material}

Twenty seven different cereal samples (wheat, rye, barley, oat, and millet) were collected immediately after harvest from three different production regions in Macedonia (Shtip, Veles and Negotino), that were grown by organic and conventional farming in the year 2013.

The number of the samples analyzed by cereal type were the following: three wheat samples organically grown and four conventionally grown; two barley samples organically grown and two samples conventionally grown, as well as three samples grown in conversion method; two oat samples organically grown and three samples conventionally grown; two rye samples organically grown and two samples conventionally grown, and two millet samples organically grown and two samples conventionally grown. The cereal variety was not taken into consideration because it was unknown for the producers for the most of the cereals.

The soil type of cereal growing differed from alluvial in Negotino and Veles region in the valley of the river Vardar to mostly sandy with large patches of red soil (crvenica) in Shtip region [Macedonian Soil Information System, 2015]. Organic farm manure was applied for growing of the organic cereals in all regions, while for the conventionally grown cereals agronomy measures according to standards were applied using mineral fertilizes with saltpeter and urea in some of them.

\section{Determination of DF and its components}

Standardized enzymatic-gravimetric method (Megazyme Total Dietary Fiber Kit) was used for determination of Soluble, Insoluble, and Total Dietary Fiber in different cereals. The method used in the investigations is based on the procedure of the methods AOAC 991.43, AOAC 985.29, AACC 32-07.01 and AACC 32-05.01 and for determination of total dietary fibre [Lee et al., 1992; Prosky et al., 1992].

The principle of the method in brief is that $1 \mathrm{~g}$ of a dried cereal sample (duplicate) is subjected to sequential enzymatic digestion by heat-stable $\alpha$-amylase, protease and amyloglucosidase. The procedure was performed on dried samples. Samples were cooked at $100^{\circ} \mathrm{C}$ with heat stable $\alpha$-amylase for gelatinization, hydrolysis and depolymerization of starch; incubated on $60^{\circ} \mathrm{C}$ with protease and amyloglucosidase; and treated with four volumes of ethanol (for precipitation of soluble fiber and removing of depolymerized protein and glucose). The residue was filtered, washed with $78 \%$ and $95 \%$ ethanol and acetone, dried and weighed. One duplicate was analyzed for protein and the other was incinerated at $525^{\circ} \mathrm{C}$ to determine ash. The protein analyses of residues were performed using the Kjeldahl method (conversion factor used to calculate $\mathrm{g}$ of protein was 6.25).

\section{Determination of soluble/insoluble dietary fibre content}

Insoluble dietary fibre (IDF) was filtered, and then the residue was washed with warm distilled water. Combined solution of filtrate and water washings were precipitated with 4 volumes of $95 \%$ ethanol $(\mathrm{EtOH})$ for soluble dietary fibre (SDF) determination. Precipitate was then filtered and dried. Both SDF and IDF residues were corrected for protein, ash and blank, for the final calculation of SDF and IDF values.

\section{Determination of total dietary fibre content}

The soluble dietary fibre (SDF) was precipitated with $\mathrm{EtOH}$, and the residue was then filtered, dried and weighed. Total dietary fibre (TDF) value was corrected for protein and ash content.

\section{Statistical analysis}

Data obtained in the analyses were tested for significance using the analysis of variance, the F-test using the software package Statgraph 3.0 (Statistical Graphics, Warrenton, Virginia, USA).

\section{RESULTS AND DISCUSSION}

The results obtained from the investigations on the content of dietary fibre and of its fractions in different cereal samples are given in Table 1. They demonstrate that among all cereals investigated which were grown by the both organic and conventional farming method, including also those grown 
by in conversion farming method: organically grown oat had maximum average values $(\%, \mathrm{db})$ of TDF $(42.00)$, and of IDF (39.22). The maximum average value $(\%, \mathrm{db})$ of SDF $(6.85)$ was found for the organically grown barley. With the conventionally grown wheat, the minimum average value of TDF $(\%, \mathrm{db})$ was observed (13.28), while the minimum average values $(\%, \mathrm{db})$ of IDF (8.06) and of SDF (0.98) were observed with the conventionally grown millet.

Our results obtained for SDF in conventionally grown rye $(3.19 \% \mathrm{db})$ were similar with those found in rye whole grain (3.7\% db) by Ragaee et al. [2006]. In that research, it was found that barley was significantly high in IDF (22.1\%), and our findings are in agreement regarding the conventionally grown barley $(20.94 \% \mathrm{db})$, (Table 1$)$. In the cited research, millet and rye contained reasonable levels of IDF (13.5\% and $14.1 \%$, respectively). Similar results were obtained in our research for the conventionally grown rye $(13.88 \% \mathrm{db})$, but in the conventionally grown millet the determined insoluble fibre fraction value $(13.80 \%, \mathrm{db})$ was among the minimum values found in all analyzed cereals, (Table 1). In regard to the TDF including resistant starch, these researchers have shown the following order: barley (24.6\%), rye $(17.8 \%)$ and millet (15.0\%), while our order for conventionally grown cereals was: barley $(22.00 \%)$, rye $(17.08 \%)$ and millet $(15.74 \%)$ and for those that were organically grown was: barley $(21.91 \%)$, rye $(15.62 \%)$, and millet (16.13\%). In addition, Ragaee et al. [2006] reported lower values of TDF in millet (11\%), with an explanation that it could be due to different genotypes. As can be seen from Table 1, our research also showed the minimum value for TDF for the conventionally grown millet $(15.74 \%)$, while the value of the organically grown millet was significant (16.13\%).

We noticed a slightly lower DF value in organically grown barley $(21.91 \%)$. Barley contains husks that are rich in insoluble DF and lignin [Salomonsson et al., 1980], and this explains the higher concentration of non-starchy polysaccharides and TDF in these cereals. The content of soluble fiber was higher in rye, barley, and wheat than in the other analyzed cereals.

The dietary fibre content was investigated in cereal grain and its parts by few researchers [Nyman et al., 1984; Kowieska et al., 2011; Devinder et al., 2012]. The values of TDF, IDF and SDF in wheat flours and cereal whole grain were determined using the enzymatic-gravimetric procedure of the AACC Method 32-07 [Ragaee et al., 2006]. It was shown that the TDF value in hard wheat was $4.59 \%$, in soft wheat $3.65 \%$, in barley $24.63 \%$, in millet $14.95 \%$ and in rye $17.77 \%$. SDF values for these cereal samples varied from 1.61 to 3.70 and for IDF from $2.98 \%$ to $14.07 \%$.

The calculated percentage of increasing/decreasing of TDF value and the value of its fractions in relation to farming type is presented in Table 2. As it can be seen from the table, an increase in TDF value was noticed in all organic cereals compared with those grown by conventional or in conversion farming type. An increase was also noticed in ISF value in all organic cereals examined with the exception of barley. Organic millet has shown a significant value of TDF and IDF. As for the SDF value, an increase was obtained only in organic barley and oat in comparison with cereals grown by conventional or in conversion farming method, with significant values for almost all growing type cereals.
TABLE 1. Content of total dietary fibre, insoluble dietary fibre and soluble dietary fibre in the investigated cereal samples.

\begin{tabular}{lccccc}
\hline Cereal & Farming & TDF $(\%, \mathrm{db})$ & $\mathrm{IDF}(\%, \mathrm{db})$ & SDF $(\%, \mathrm{db})$ \\
\hline \multirow{2}{*}{ Wheat } & $\mathrm{C}$ & $13.28 \pm 0.72$ & $12.17 \pm 0.66$ & $1.11 \pm 0.31$ \\
& $\mathrm{O}$ & $14.37 \pm 1.54$ & $13.95 \pm 1.72$ & $0.43 \pm 0.39$ \\
\hline \multirow{2}{*}{ Barley } & $\mathrm{C}$ & $22.00 \pm 2.28$ & $20.94 \pm 2.41$ & $1.06 \pm 0.91$ \\
& $\mathrm{O}$ & $21.91 \pm 2.01$ & $15.06 \pm 1.84$ & $6.85 \pm 3.85$ \\
& $\mathrm{ICV}$ & $20.99 \pm 0.44$ & $15.51 \pm 4.36$ & $5.48 \pm 4.80$ \\
\hline \multirow{2}{*}{ Oat } & $\mathrm{C}$ & $37.86 \pm 1.01$ & $36.08 \pm 0.42$ & $1.78 \pm 1.28$ \\
& $\mathrm{O}$ & $42.00 \pm 1.39$ & $39.22 \pm 0.58$ & $2.78 \pm 1.25$ \\
\hline \multirow{2}{*}{ Rye } & $\mathrm{C}$ & $17.08 \pm 2.05$ & $13.88 \pm 1.28$ & $3.19 \pm 0.39^{\mathrm{a}}$ \\
& $\mathrm{O}$ & $15.62 \pm 3.26$ & $14.08 \pm 3.13$ & $1.54 \pm 0.12^{\mathrm{b}}$ \\
\hline \multirow{2}{*}{ Millet } & $\mathrm{C}$ & $15.74 \pm 1.48$ & $13.80 \pm 1.13$ & $1.94 \pm 0.35$ \\
\hline
\end{tabular}

C - Conventional; O - Organic; ICV - In conversion; TDF - Total dietary fibre; IDF - Insoluble dietary fibre; SDF - Soluble dietary fibre; Values are means \pm sd; a,b Values in the same row with no common letters differ significantly $(\mathrm{p}<0.05)$.

TABLE 2. Percentage of increasing/decreasing of TDF value and of its fractions in relation to farming type.

\begin{tabular}{lcccc}
\hline Cereal & Relation & TDF $(\%, \mathrm{db})$ & ISF $(\%, \mathrm{db})$ & SDF $(\%, \mathrm{db})$ \\
\hline Wheat & $\mathrm{O} / \mathrm{C}$ & $+7.59 \%$ & $+12.75 \%$ & $-61.26 \%$ \\
\hline \multirow{2}{*}{ Barley } & $\mathrm{O} / \mathrm{C}$ & $-0.41 \%$ & $-28.08 \%$ & $+84.52 \%$ \\
& $\mathrm{ICV} / \mathrm{C}$ & $-4.59 \%$ & $-25.93 \%$ & $+80.66 \%$ \\
\hline Oat & $\mathrm{O} / \mathrm{C}$ & $+9.86 \%$ & $+8.01 \%$ & $+35.97 \%$ \\
\hline Rye & $\mathrm{O} / \mathrm{C}$ & $-8.55 \%$ & $+1.42 \%$ & $-51.72 \%$ \\
\hline Millet & $\mathrm{O} / \mathrm{C}$ & $+43.96 \%$ & $+49.43 \%$ & $-80.61 \%$ \\
\hline
\end{tabular}

$\mathrm{C}$ - Conventional; O - Organic; ICV - In conversion; TDF - Total dietary fibre; IDF - Insoluble dietary fibre; SDF - Soluble dietary fibre.

Our earlier studies on the influence of the variety, growing climate conditions and the production type on the oat fiber content, have shown that it was decreased by $5.8 \%$ compared to that conventionally grown oat [Spasova \& Menkovska, 2009].

\section{CONCLUSIONS}

Both the cereal type and the farming method had an influence on the values of the TDF, IDF and SDF content in cereals. Organic farming method proved to be effective for oat for all examined DF fractions. Barley grown by either organic or in conversion farming method proved to have the highest SDF value among the other cereals investigated, whereas oat produced by organic farming method exhibited the highest TDF and IDF value.

The conclusions drown in this paper are on the basis of research on one-year production period assuming that the DF 
content in cereals is an heredity trait. The research presented here should be repeated for a longer production period, which will be the aim of future work. In that way, the influence of year, production region and cereal type including the variety should be investigated with a greater certainty. The associations between the production type and DF content in cereals should be also investigated.

\section{RESEARCH FUNDING}

This research is a part of a scientific project which was supported by the integrative fund of the Ss.Cyril and Methodius University in Skopje, Macedonia.

\section{CONFLICT OF INTEREST}

Authors declare no conflict of interests.

\section{REFERENCES}

1. AACC International Methods 32-05.01, 32-07.01, 32-28.01, 32-31.01, 32-32.01, 32-33.01, 32-40.01, 32-41.01, and 32-45.01. AACC International Approved Methods of Analysis, 11th Ed., 2009, AACC International PRESS, St. Paul, MN, U.S.A.

2. AOAC International Official Methods 985.29, 991.42, 991.43, 999.03, 993.19, 997.08, 999.03, 2000.11, 2001.02, 2001.03, 2002.02, and 2009.01. Official Methods of Analysis of AOAC International, 18th Ed., 2005, Horwitz, W., ed. AOAC International, Gaithersberg, MD, U.S.A.

3. Babio N., Balanza R., Basulto J., Bulló M., Salas-Salvadó J., Dietary fibre: influence on body weight, glycemic control and plasma cholesterol profile. Nutr. Hosp., 2010, 25, 327-40.

4. Cho I., Blaser M.J., The human microbiome: at the interface of health and disease. Nat. Rev. Genet., 2012, 13, 260-270.

5. Council Regulation (EC) No. 834/2007 of 28 June 2007 on organic production and labeling of organic products and repealing Regulation (EEC) No. 2092/91. [http://ec.europa.eu/agriculture/organic/eu-policy/eu-rules-on-production/legal frame/ index en.htm].

6. Devinder D., Mona M., Hradesh R., Patil R.T., Dietary fibre in foods: a review. J. Food Sci. Technol., 2012, 49, 255-266.

7. Devries J.W., Dietary fiber: the influence of definition on analysis and regulation. J. AOAC Int., 2004, 87, 682-706.

8. EFSA Panel on Dietetic Products, Nutrition and Allergies (NDA). Scientific opinion on dietary reference values for carbohydrates and dietary fibre. EFSA Journal, 2010, 8, 1462-1477.

9. Hemery Y., Rouan X., Lullien-Pellerin V., Barron C., Abecassis J., Dry process to develop wheat fractions and products with enhanced nutritional quality. J. Cereal Sci., 2007, 46, 327-347.

10. FAO/WHO Food Standards Programme, Secretariat of the CODEX Alimentarius Commission: CODEX Alimentarius (CODEX) Guidelines on Nutrition Labeling CAC/GL 2-1985 as Last Amended 2010. Rome: FAO, 2010.

11. Jones J.M., Dietary fiber future directions: integrating new definitions and findings to inform nutrition research and communication. Adv. Nutr., 2013, 4, 8-15.

12. Kristensen M., Jensen M.G., Dietary fibres in the regulation of appetite and food intake. Importance of viscosity. Appetite, 2011, 56, 65-70.
13. Kowieska A., Lubowicki R., Jaskowska I., Chemical composition and nutritional characteristics of several cereal grain. Acta Sci. Pol., Zootechnica 2011, 10, 37-50.

14. Law of organic agricultural production, Official paper of RM No.146/2009. Available from: [http://www.mzsv.gov.mk/files/ Zakon_za_organsko_zemjodelsko_proizvodstvo.pdf] (in Macedonian).

15. Lee S.C., Prosky L., DeVries J.W., Determination of total, soluble and insoluble dietary fiber in food-enzymatic-gravimetric method MES-TRIS buffer: Collaborative Study. J. Anal. Chem., 1992, 75, 395-416.

16. Macedonian Soil Information System, 2015. [http://www. maksoil.ukim.mk/masis/] (in Macedonian).

17. McCleary B.V., Sloane N., Draga A., Lazarewska I., Measurement of total dietary fiber using AOAC method 2009.01 (AACC International Approved Method 32-45.01): Evaluation and updates. Cereal Chem., 2013, 90, 396-414.

18. Menkovska M., Levkov V., Gjorgovska N., Nikolova N., Pacinovski N., Stanoev V., Nikolovski M., Quality properties of cereal crop in relation with organic versus conventional farming. MJAS, 2014, 4, 23-26.

19. Morgan K., Murdoch J., Organic vs. conventional agriculture: knowledge, power and innovation in the food chain. Geoforum, 2000, 31, 159-173.

20. Nyman M., Siljeström M., Pedersen B., Bach Knudsen K.E., Asp N.G, Johannsons C.G.. Eggum B.O., Dietary fiber content and composition in six cereals at different extraction rates. Cereal Chem., 1984, 61, 14-19

21. Prosky L., Asp N.G., Schweizer T.F., DeVries J.W., Furda I., Determination of insoluble and soluble dietary fiber in foods and food products: Collaborative study. J. AOAC, 1992, 75, 360-367.

22. Ragaee S., Abdel-Aal E.M., Noaman M., Antioxidant activity and nutrient composition of selected cereals for food use. Food Chem., 2006, 98, 32-38.

23. Salomonsson A.C., Theander O., Aman P., Composition of normal and high-lysine barley. Swedish J. Agric. Res., 1980, 10, $11-16$

24. Saulnier L., Sado P.E., Branlard G., Charmet G., Guillan F., Wheat arabinoxylans: Exploiting variation in amount and composition to develop enhanced varieties. J. Cereal Sci., 2007, 46, 261-281.

25. Spasova D., Menkovska M., Comparative analysis of oat quality grown in organic and conventional conditions. 2009, in: Biotechnology in Animal Husbandry, Book 2, Institute for Animal Husbandry, Belgrade-Zemun, Serbia, pp.1163-1170.

26. USDA Agricultural Marketing Service. Fact Sheet: National Organic Production and Handling Standards.. Accessed online April 2008.

27. Vernay M., Aïdara M., Salanave B., Deschamps V., Malon A., Oleko A., Mallion, J.M., Hercberg S., Castetbon K., Diet and blood pressure in 18-74-year-old adults: the French Nutrition and Health Survey (ENNS, 2006-2007). J. Hypertens., 2012, 30, 1920-1927.

Submitted: 25 November 2016. Revised: 9 May and 22 September 2016. Accepted: 23 September 2016. Published on-line: 21 November 2016. 